\title{
Omobracbyiulus mesorientalis sp.n., the first record of the millipede genus Omobracbyiulus Lohmander, 1936 in the Near East (Diplopoda: Julida: Julidae: Brachyiulini)
}

\section{Omobracbyiulus mesorientalis sp.n., первая находка дипмопод рода Omobrachyiulus Lohmander, 1936 на Бцижнем Востоке (Diplopoda: Julida: Julidae: Brachyiulini)}

\author{
B. Vagalinski ${ }^{1}$, S.I. Golovatch ${ }^{2}$ \\ Б. Вагалински ${ }^{1}$, С.И. Головач ${ }^{2}$
}

\footnotetext{
${ }^{1}$ Institute of Biodiversity and Ecosystem Research, Bulgarian Academy of Sciences, 2 Yurii Gagarin Street, 1113, Sofia, Bulgaria. E-mail: boyan_vagalinski@excite.com

${ }^{2}$ Institute for Problems of Ecology \& Evolution, Russian Academy of Sciences, Leninsky prospect 33, Moscow 117051, Russia. E-mail: sgolovatch@yandex.ru

${ }^{2}$ Институт проблем экологии и эволюции РАН, Ленинский просп. 33, Москва 117051, Россия.
}

KEY WORDS: taxonomy, new species, Israel, Lebanon.

КЛЮЧЕВЫЕ СЛОВА: таксономия, новый вид, Израиль, Ливан.

ABSTRACT. The first species of Omobrachyiulus is described from Israel and Lebanon: $O$. mesorientalis sp.n. This new and yet sole Near East species of the genus is distinguished from congeners both in certain morphological characters, primarily gonopodal ones, and in likely representing one of the southernmost outliers not only of its mostly Caucasian genus, but also of the entire, largely circum-Mediterranean tribe Brachyiulini it belongs to. Palaeogeographic evidence dating back to the Eastern Paratethys in the Miocene and Pliocene is brought up to possibly explain the modern distribution pattern of both Omobrachyiulus and $O$. mesorientalis sp.n.

How to cite this article: Vagalinski B., Golovatch S.I. 2019. Omobrachyiulus mesorientalis sp.n., the first record of the millipede genus Omobrachyiulus Lohmander, 1936 in the Near East (Diplopoda: Julida: Julidae: Brachyiulini) // Arthropoda Selecta. Vol.28. No.1. P.1-7. doi: 10.15298/arthsel. 28.1.01

РЕЗЮМЕ. Описан первый вид рода Omobrachyiulus их Израиля и Ливана: O. mesorientalis sp.n. Этот новый и пока единственный ближневосточный вид рода отличается от других видов как рядом морфологических признаков, прежде всего, строением гоноподов, так и тем, что, вероятно, является одним из самых южных изолятов не только своего, в основном, кавказского рода, но и всей, главным образом, кругосредиземноморской трибы Brachyiulini, куда он относится. Для возможного объяснения такого типа современного ареала и рода Omobrachyiulus, и O. mesorientalis sp.n. приводятся палеогеографические данные, относящиеся к Вос- точному Паратетису и датируемые со времен миоцена и плиоцена.

\section{Introduction}

The genus Omobrachyiulus Lohmander, 1936 is one of the 13 genera currently recognized in the chiefly circum-Mediterranean tribe Brachyiulini [Vagalinski, Lazányi, 2018]. It comprises ca 25 known species, mostly distributed in the Caucasus [Attems, 1899; Verhoeff, 1921; Lohmander, 1928, 1936; Golovatch, 1981], including more than 10 species awaiting description [Vagalinski, Golovatch, in prep.]. Only a few members of the genus are known outside that region, these occurring in confined areas in the Carpathians, the Rhodope Mts or Greek islands, plus one subspecies, $O$. brachyurus brachyurus (Attems, 1899), with a broader distribution across the Caucasus, Hyrcania and the East Pontic Mountains, Turkey.

Here we describe a new species from Israel and Lebanon, with the number of published species of Omobrachyiulus amounting to 13 .

\section{Material and methods}

The studied specimens were collected with pitfall traps or by hand, and are currently kept in $70 \%$ ethanol in the collections of the Zoological Museum, Tel Aviv University (ZMTA), the Zoological Museum, University of Moscow (ZMUM), the National Museum of Natural History, Sofia (NMNHS), and the Natural History Museum of Denmark, Copenhagen (ZMUC).

Drawings of body structures were made under Wild or MBS-10 stereo microscopes. Whole body pictures 

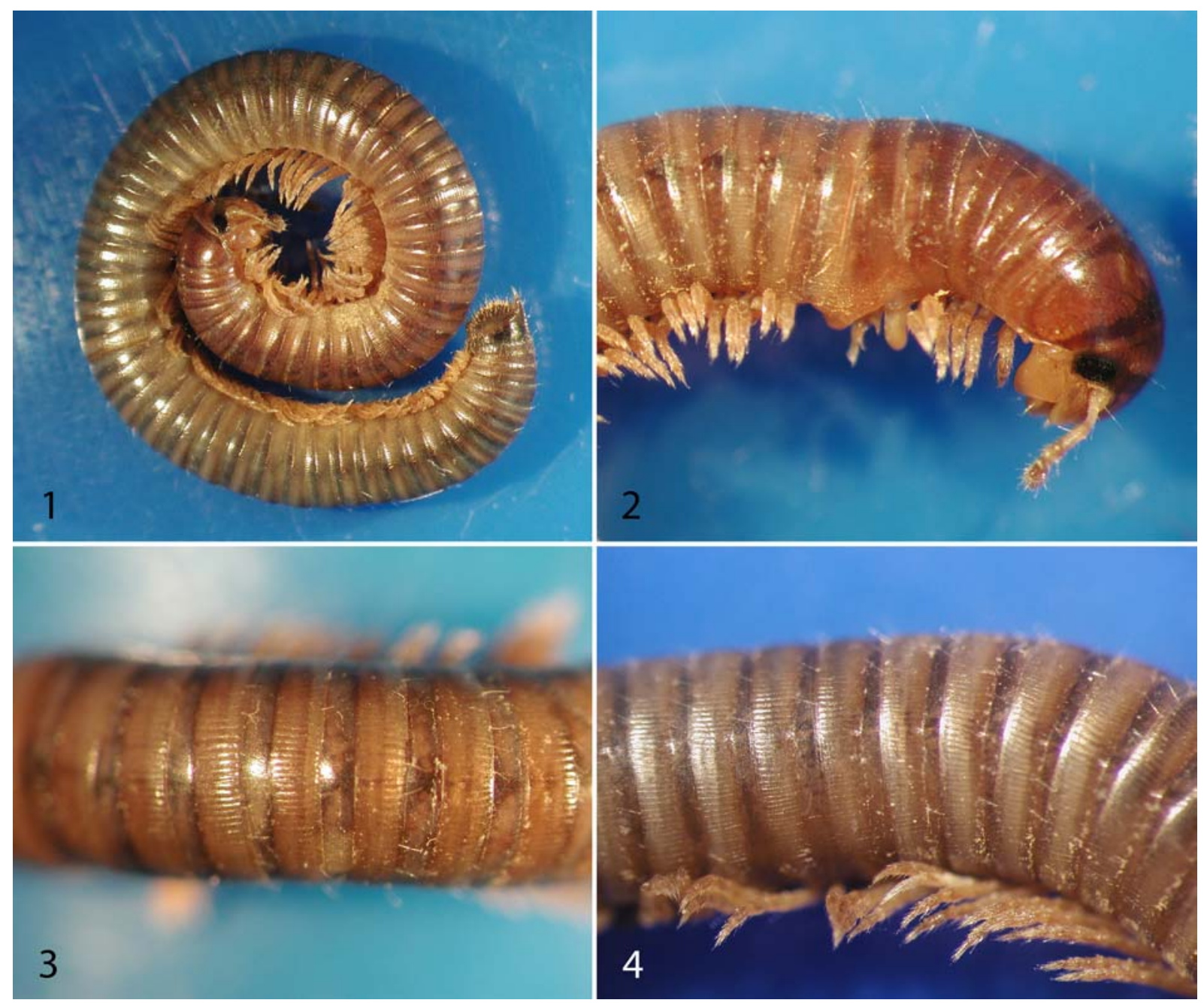

Figs 1-4. Habitus of Omobrachyiulus mesorientalis sp.n., male paratypes from Nahal Kziv: 1 - whole body, lateral view; 2 anterior part of body, lateral view; 3-4- mid-body, dorsal and lateral views, respectively. Pictures by J. Wytwer, taken not to scale.

Рис. 1-4. Общий вид Omobrachyiulus mesorientalis sp.n., самцы-паратипы из Nahal Kziv: 1 - тело целиком, сбоку; 2 передняя часть тела, сбоку; 3-4 - середина тела, соответственно сверху и сбоку. Сфотографировано J. Wytwer, без масштаба.

were taken with a Samsung digital camera. Multilayer colour micrographs were obtained with the aid of a ProgRes C7 camera connected to a Zeiss Axio Imager 2 light microscope, followed by focal stacking with CombineZM software. Scanning electron micrographs were taken with a JEOL JSM-5510 scanning electron microscope. Final processing of the figures was done in Adobe Photoshop CC 2014.

The terminology of the gonopodal and vulval structures is after Vagalinski \& Lazányi [2018].

\section{Results}

\section{Omobrachyiulus mesorientalis sp.n.} Figs 1-22, Map.

Holotype $O^{\text {T }}$ (unbroken) (ZMTA), Israel, Upper Galilee, Nahal Kziv (= Nahal Keziv), deciduous forest near stream, pitfall traps, NFS7-7, 17-31.I.1999, Michael Finkel leg.

Paratypes. All from the same locality and taken with pitfall traps by the same collector as the holotype: $10^{x}$ (in 4 parts, gonopods dissected, right half prepared for SEM) (NMNHS), NFS59, 17-31.I.1999; 3 O $^{7}$ (intact, two unbroken, one with missing posterior half), 2 우, (one in 2 pieces; the other in 4 pieces, leg-pair 2 with vulvae dissected, right vulva prepared for SEM), 1 juv. O (unbroken) (ZMTA), B4-3, 12.XII.1998-2.I.1999; 1 O$^{7}$ (with missing caudal half, penis dissected), 3 우 (one unbroken, the others in

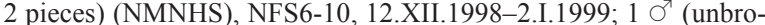
ken) (ZMUM), NFS7-2; 12.XII.1998-2.I.1999; 1 O (unbroken) (ZMUM), NFS6-5, 12.XII.1998-2.I.1999; 5 o O $^{7}$ (two unbroken, two in 2 parts), 1 premature 9 (unbroken), 4 juv. (two unbroken, two in 2 parts) (ZMTA), $1 \mathrm{O}^{7}$ (ZMUC), B4-1, 17-31.I.1999; $1 \mathrm{O}^{7} ; 3$ 오 (one in 2 parts with dissected vulvae), 1 fragm. juv. (ZMTA), NFS7-3, 17-31.1.1999; 1 ㅇ (ZMUC), B4-5, 17.I-31.I.1999.

$2 \mathrm{O}^{7} \sigma^{7}$ (prep. 4/2004SG and prep. 18/2003SG), 1 juv. $\sigma^{7}$ (ZMUM), Mt Meron, N slope, Quercus forest, 6.III.2003, S. Golovatch leg.

$1 \mathrm{O}^{\prime \prime}$ (in 2 parts, gonopods dissected), 1 (NMNHS), Lebanon, near Jeita, 10.VII.1972, P. Beron leg.

Non-types. All from the same locality and taken with pitfall traps by the same collector as the holotype: 19 (ZMTA), NFS7-8, 12.XII.1998-2.I.1999; $1 \mathrm{O}^{7}$ (fragmented), 2 우 1 fragment (ZMTA), NFS7-5, 12.XII.1998-2.I.1999; 2 juv. (ZMTA), NFS6-8, 1731.I.1999; 2 juv. (ZMTA), NFS7-8, 12.XII.1998-2.I.1999; 1 juv. O' (ZMTA), NFS7-8, 17-31.X.1998; 1 क (ZMUM), NFS7-4, 


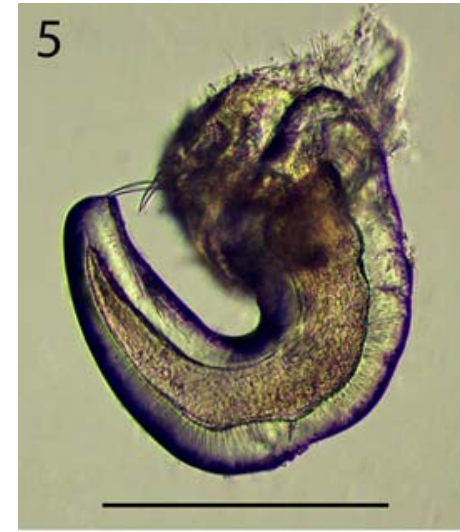

7

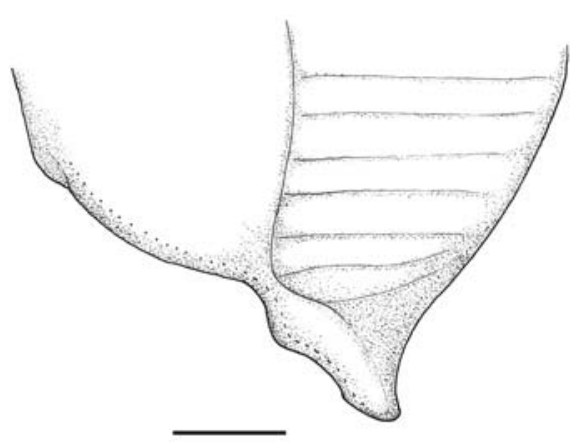

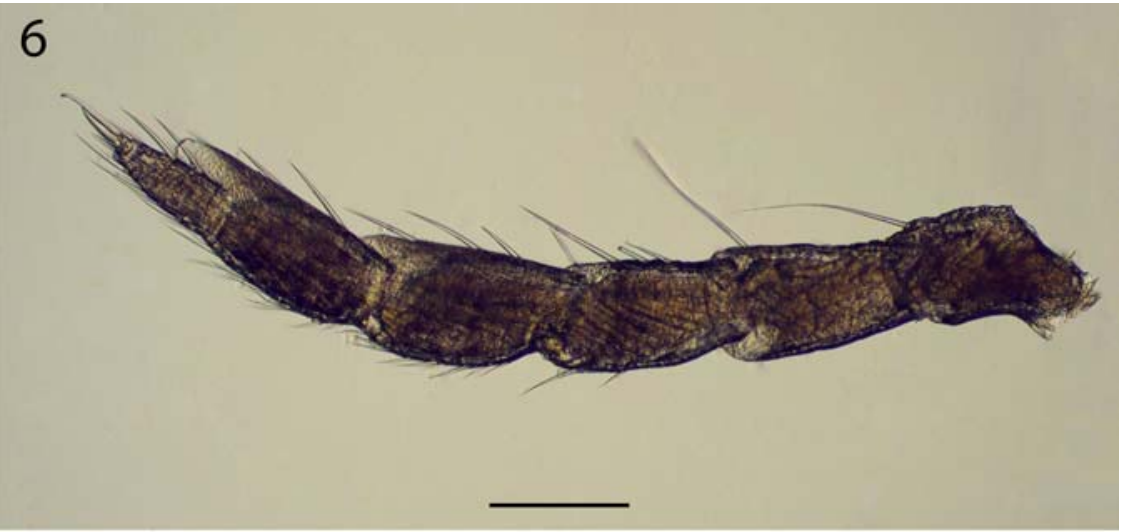

8
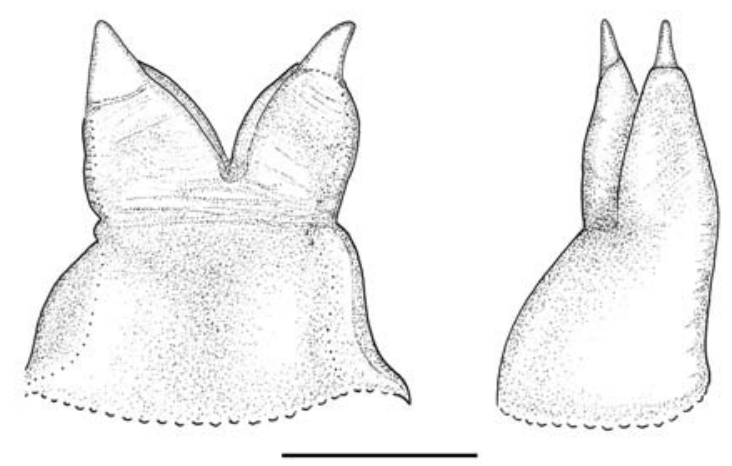

Figs 5-9. Non-gonopodal characters of Omobrachyiulus mesorientalis sp.n., male paratypes from Nahal Kziv: 5 — right leg 1, mesal view; 6 - left leg 2, oral view; 7 - left edge of pleurotergum 7 , ventrolateral view; 8-9 - penis, caudal and lateral views, respectively. Scale bars: $0.2 \mathrm{~mm}$.

Рис. 5-9. Не связанные с гоноподами признаки у Omobrachyiulus mesorientalis sp.n., самцы-паратипы из Nahal Кеziv: 5 правая нога 1, изнутри; 6 - левая нога 2, спереди; 7 - левый край плейротергита 7, одновременно снизу и сбоку; 8-9 - пенис, соответственно сзади и сбоку. Масштаб: 0,2 мм.

12.XII.1998-2.I.1999; 1 q (ZMTA), NFS5-10, 17-31.X.1998; 1 juv. + (ZMTA), B4-10, 12.XII.1998-2.I.1999; 1 fragmented $\sigma^{7}$ (ZMTA), NFS7-8, 17-31.X.1998, 1 fragmented + (ZMTA), NFS56; 12.XII.1998-2.I.1999; 1 ○, 2 क्ष (ZMUM), NFS5-6, $17-$ 31.I.1999; 1 , 1 juv., 1 \% (fragmented), 3 ㅇ, 3 juv. (ZMTA), NFS6-10, 12.XII.1998-2.I.1999.

DIAGNOSIS. A species of the genus Omobrachyiulus Lohmander, 1936, as defined by Vagalinski \& Lazányi [2018], with the exception of the opisthomeral basoposterior process, which is completely vestigial in the new species. Differs from all congeners mostly by the rounded, soleshaped promere, and in the opisthomere having a pointed, microserrate, anterior process, and a strongly compressed, lobe-like remnant of the basoposterior process, this latter being devoid of a freely protruding apical part; as well as by the hypoproct being subtriangular rather than trapezoidal or rounded.

ETYMOLOGY. Derived from its Near East provenance.

DESCRIPTION. Measurements: holotype $\sigma^{7}$ in $\mathrm{S} \mathrm{X}$, $56+2+\mathrm{T}, \mathrm{l}=32 \mathrm{~mm}, \mathrm{~h}=1.9 \mathrm{~mm}$. Paratype $\sigma^{7} \sigma^{7}$ in S IX-XI, $53-58+2+\mathrm{T}, 1=24-37 \mathrm{~mm}, \mathrm{~h}=1.7-2.15 \mathrm{~mm}$. Paratype in $\mathrm{S} \mathrm{X}, 54-58+2+\mathrm{T}, \mathrm{l}=29-37 \mathrm{~mm}, \mathrm{~h}=2.3-2.9 \mathrm{~mm}$.

Colouration: Mostly different shades of brown (Figs 14); prozonae darker than metazonae, chocolate brown around ozopores, dark brown-grey on dorsum; head with a blackish band between eye patches; collum chocolate brown, darker along margins; pre-anal ring darker than remaining body rings; legs and antennae brownish beige; a continuous blackish axial line.

External structures: 2 frontal, 4 supralabral (with an additional $5^{\text {th }}$ median seta in one paratype $\sigma^{7}$ ), 24-35 labral setae. Antennomeres 3, 4 and 5 subequal in length, ca 0.7 times as long as 2, and 1.6-2.2 times as long as 6. Gnathochilarium of normal julid appearance; promentum relatively large: $0.3-0.4$ times as long as entire gnathochilarium; 4 setae on each lingual lamella. Collum smooth dorsally, with several, up to 15 short and shallow striae near posterolateral corner; lateral section of anterior margin characteristically concave.

Prozonae with scattered, short, shallow, non-parallel striae. Metazonae deeply striated, with $10-11$ striae in a square with sides equal to metazonal length just below ozopore level; hind margins with a dense whorl of setae, ca 1/3-3/5 of metazonal length. Ozopores placed tight behind pro-metazonal suture in anterior to mid-body rings, but slightly further back (ca half of their diameter) in posterior rings; suture not or very slightly incised in front of ozopores. Tarsi of mid-body legs $0.75-0.9$ as long as tibiae.

Telson (Fig. 1): Epiproct straight, somewhat compressed dorsoventrally (this being more pronounced in females), ending with a long, slender, pointed, hyaline tip (often bro- 


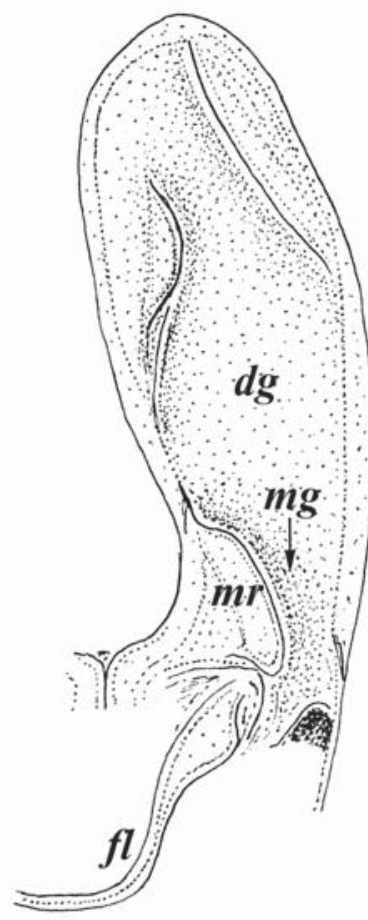

10

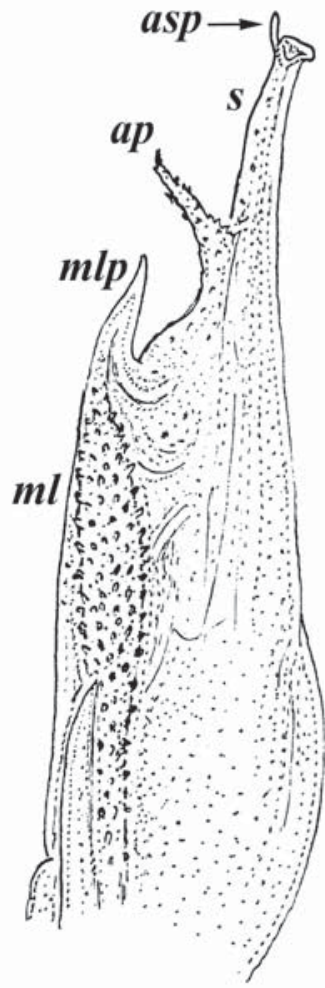

11

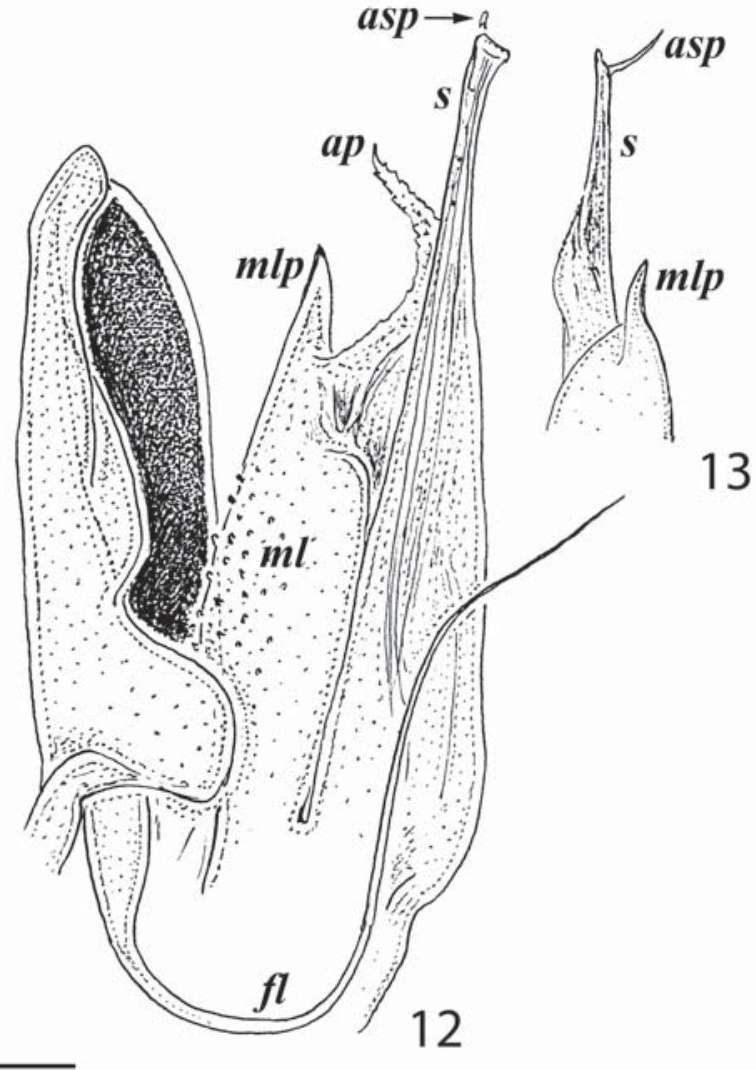

Figs 10-13. Gonopods of Omobrachyiulus mesorientalis sp.n., male paratype from Nahal Kziv: 10 - left promere, caudal view; 11 right opisthomere, lateral view; 12 - left pair of gonopods, mesal view; 13 - distal part of right opisthomere, oral view. Abbreviations: $a p$ - anterior process, asp — anterior process of solenomere, $d g$ - distal groove, $f l-$ flagellum, $m g-$ median groove, $m l-$ mesomeroidal lobe, $m l p$ - apical process of mesomeroidal lobe, $m r$ - median ridge, $s$ - solenomere. Scale bar: $0.2 \mathrm{~mm}$.

Рис. 10-13. Гоноподы Omobrachyiulus mesorientalis sp.n., самец-паратип из Nahal Kziv: 10 - левый промер, сзади; 11 правый опистомер, сбоку; 12 - левая пара гоноподов, изнутри; 13 - дистальная часть правого опистомера, спереди. Обозначения: $a p$ - передний отросток, $a s p$ - передний отросток соленомера, $d g$ - дистальный желобок, $f l$ - жгутик, $m g$ - медиальный желобок, $m l$ - мезомероидная доля, $m l p$ - вершинный отросток мезомероидной доли, $m r-$ медиальный гребень, $s-$ соленомер. Масштаб: 0,2 мм.

ken off) turned somewhat ventrad, slightly surpassing the longest anal setae, densely setose. Hypoproct broad, subtriangular, with a narrow, sharply pointed tip protruding more than $1 / 3$ behind rear margin of paraprocts in males, this being blunt and barely protruding in females; ventral face densely setose. Paraprocts densely setose, without distinct rows of short and stiff setae along caudal margins.

Male sexual characters: Mandibular stipites (Figs 1, 2) moderately enlarged, protruding mostly anteriad, forming a narrowly rounded, anteroventral corner. Leg-pair 1 (Fig. 5) typical parallel hooks with slightly diverging tibial outgrowths, without tarsal remnants. Leg-pair 2 (Fig. 6) and following pairs with two adhesive pads, one each on postfemur and tibia. Leg-pairs 2-7 with pronouncedly crested tibial pads, with a distinct distal lobe partly covering the tarsus. Pleurotergum 7 (Fig. 7) ventrally forming rather small, subtriangular plates originating mostly from metazona and protruding ventrad behind gonopods. Penis (Figs 8, 9) stout, only slightly compressed sagittally, broadest at base, conspicuously constricted near middle; apical lobes welldifferentiated, diverging, ending up in subtriangular terminal lamellae.
Gonopods (Figs 10-19): In situ ca 1/3 jutting out of gonopodal sinus, protruding completely ventrad, solenomere slightly longer than promere. Promere (Figs 10, 14 \& 15) roughly sole-shaped, slightly bent mesad, narrowing basad; with a pronounced, but very short, median ridge $(\boldsymbol{m r})$, and a very deep and narrow median groove ( $\boldsymbol{m g})$; and with a broad and long distal groove $(\boldsymbol{d g})$; the two promeres basally very tightly fused to each other. Flagellum $(f l)$ slightly longer than promere's height, thin, almost thread-like distally. Opisthomere (Figs 11, 13, 16-19, and in Fig. 12) completely devoid of a basoposterior process, the latter represented only by a weakly pronounced lobe, lacking a freely protruding apical part; mesomeroidal lobe $(\boldsymbol{m l})$ massive, with a broad and flattened anterior face, protruding apically into a pointed, horn-like process $(\boldsymbol{m l} \boldsymbol{p})$; with a slender, sharply pointed, microserrated, anterior process ( $a p$ ) originating immediately distal to mesomeroidal lobe, directed anterodistad. Solenomere (s) long and slender, ending up in a lamellar, somewhat folded structure; anteromedially bearing a fine and pointed anterior process (asp), more or less turned anteriad apically; a compact group of short spiniform filaments $(s f)$ behind flagellum channel $(f c)$ at solenomeral 

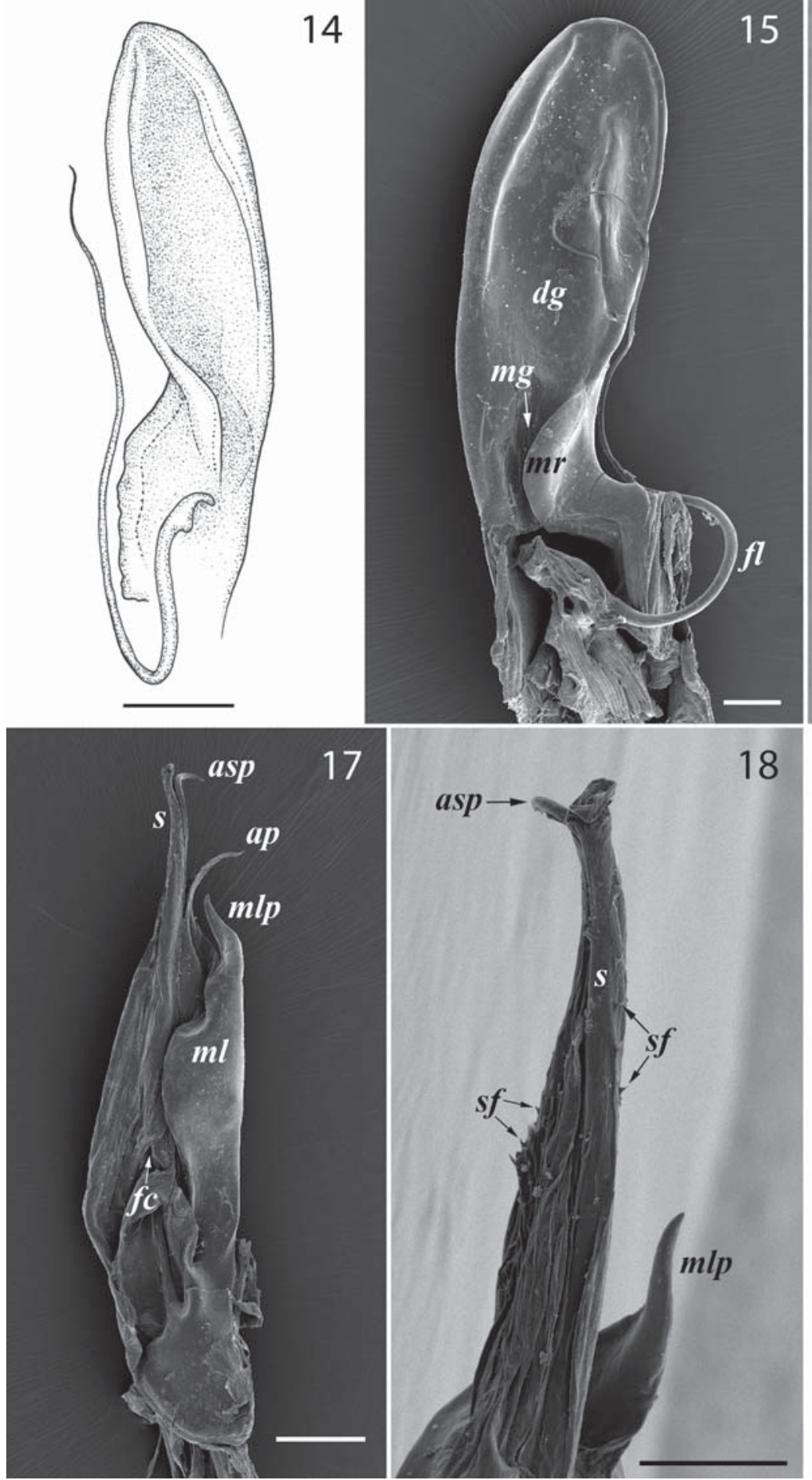

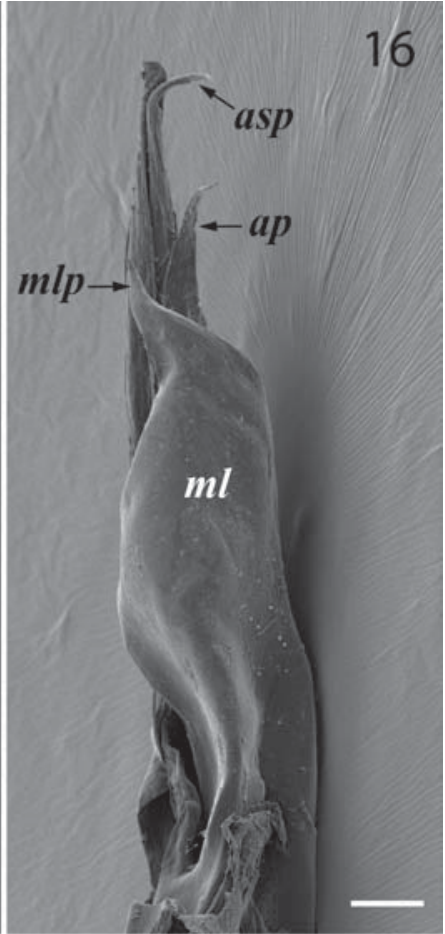

19

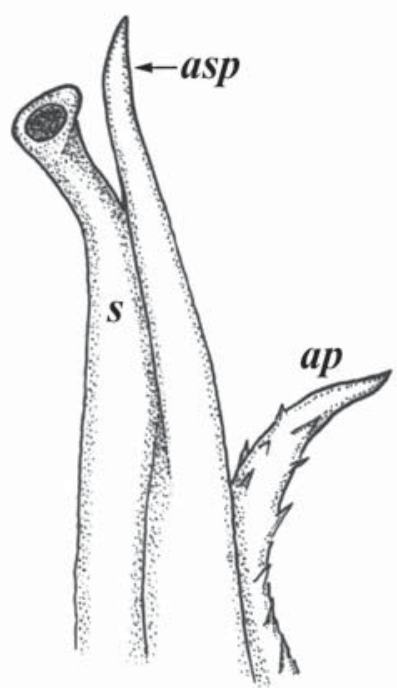

Figs 14-19. Gonopods of Omobrachyiulus mesorientalis sp.n., male paratypes from Jeita $(14,19)$ and Nahal Kziv $(15-18): 14$ - left promere, caudal view; 15 - right promere, caudal view; 16-18 — right opisthomere, oral, mesal and mesocaudal views, respectively; 19 distal part of left opisthomere, lateral view. Abbreviations: ap — anterior process, asp - anterior process of solenomere, $d g$ - distal groove, $f l$ - flagellum, $f c$ - flagellum channel, $m g$ - median groove, $m l$ - mesomeroidal lobe, $m l p$ - apical process of mesomeroidal lobe, $m r$ - median ridge, $s$ - solenomere, $s f$ - spiniform filaments. Scale bars $0.1 \mathrm{~mm}(15,16,18)$ and $0.2 \mathrm{~mm}(14,17,19)$.

Рис. 14-19. Гоноподы Omobrachyiulus mesorientalis sp.n., самцы-паратипы из Jeita $(14,19)$ и Nahal Kziv $(15-18): 14$ - левый промер, сзади; 15 - правый промер, сзади; 16-18 - правый опистомер, соответственно спереди, изнутри и одновременно изнутри и сзади; 19 - дистальная часть левого опистомера, сбоку. Обозначения: ap - передний отросток, asp - передний отросток соленомера, $d g$ - дистальный желобок, $f l$ - жгутик, $f c$ - канал жгутика; $m g$ - медиальный желобок, $m l$ - мезомероидная доля, $m l p$ - вершинный отросток мезомероидной доли, $m r$ - медиальный гребень, $s$ - соленомер; $s f$ - шиповидные выросты. Масштаб: 0,1 мм $(15,16,18)$ и 0,2 мм $(14,17,19)$. 

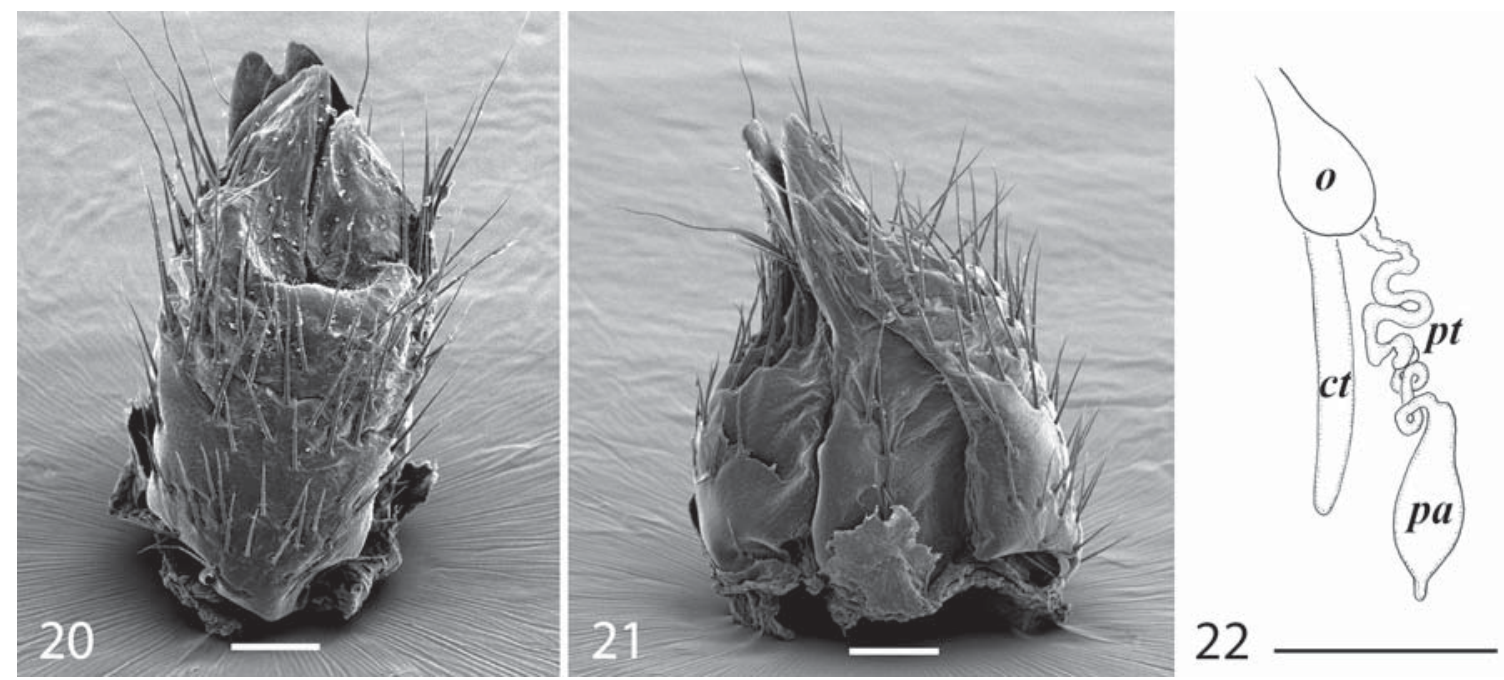

Figs 20-22. Vulvae of Omobrachyiulus mesorientalis sp.n., paratype female from Nahal Kziv: 20-21 — right vulva, mesocaudal and caudolateral views, respectively; 22 - receptaculum seminis. Abbreviations: $c t$ - central tube, $o$ - opening, $p a$ - posterior ampulla, $p t$ posterior tube. Scale bars: $0.2 \mathrm{~mm}(22) ; 0.1 \mathrm{~mm}(20,21)$.

Рис. 20-22. Вульвы у Omobrachyiulus mesorientalis sp.n., самка-паратип из Nahal Kziv: 20-21 - правая вульва, соответственно одновременно изнутри и сзади и сзади и сбоку; 22 - семяприемник. Обозначения: $c t$ - центральная трубка, $o-$ отверстие, $p a-$ задняя ампула, $p t$ - задняя трубка. Масштаб: 0,2 мм (22); 0,1 мм (20, 21).

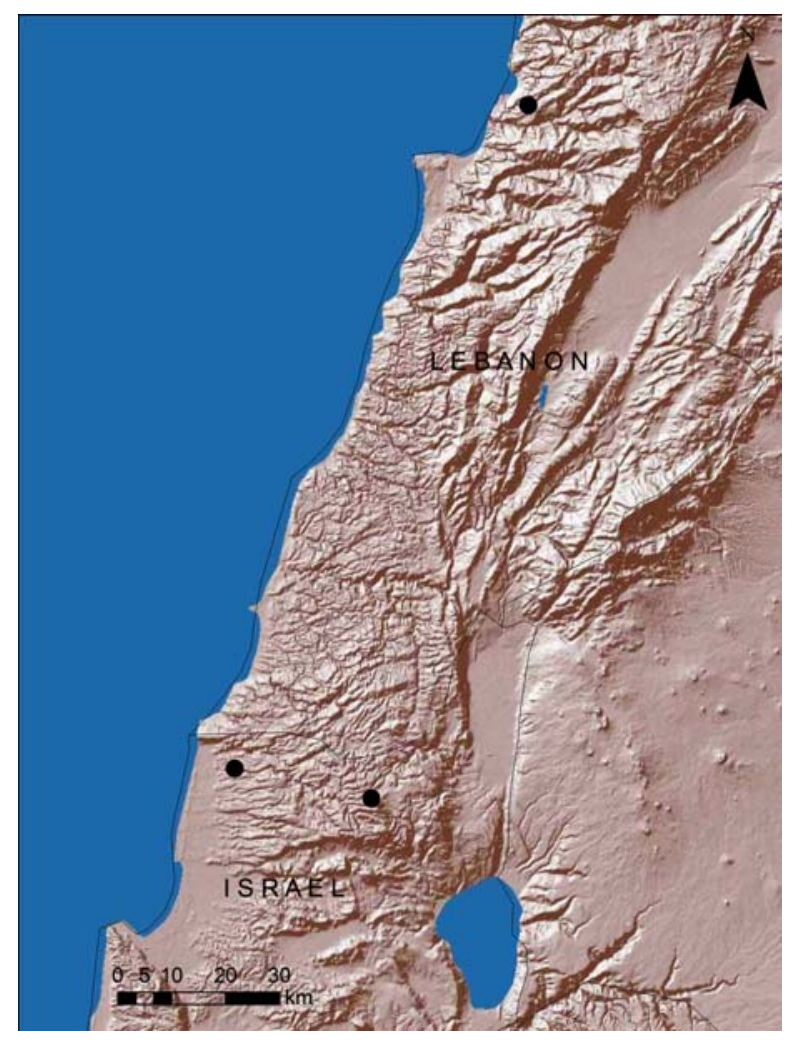

Map. Currently known records of Omobrachyiulus mesorientalis sp.n.

Карта. Ныне известные места находок Omobrachyiulus mesorientalis sp.n.

mid-height, and a sparse row of similar spines frontal to channel.

Female sexual characters: Leg pairs 1 and, to a lesser extent, 2 in mature females thicker than following legs.
Vulva (Figs 20,21) rather stout and compact, slightly compressed on sides; bursa slightly asymmetrical: lateral valve somewhat higher than mesal one; side sclerites apically ending up in large hyaline protrusions; operculum narrow, placed entirely on top of bursa; operculum as high as, or slightly exceeding, bursa; both bursa and operculum densely covered with long setae. Receptaculum seminis (Fig. 22) consisting of a nearly straight, finger-shaped, central tube (ct), and a thin, strongly twisted, posterior tube ( $\boldsymbol{p t})$ ending up in a rather spacious, bottle-like, posterior ampulla ( $p a)$.

NOTE. The gonopods of the male from Lebanon slightly differ from those in the Israeli specimens, in particular by the promere being more slender and apically tapering rather than broadly rounded, and by the anterior solenomeral process being very slightly, rather than abruptly, turned anteriad. However, these details can hardly be regarded as anything more than intraspecific variations.

\section{Concluding remarks}

Omobrachyiulus mesorientalis sp.n. appears to be the morphologically most isolated species of the genus in showing a roughly triangular rather than rounded or trapezoidal hypoproct, and a completely rudimentary basoposterior process of the opisthomere. The former character is widespread among the Brachyiulini, with the exception of the genus Iraniulus Attems, 1951 and the nominotypical subgenus of Megaphyllum Verhoeff, 1894, both showing a condition of the hypoproct being similar to that seen in all previously known species of Omobrachyiulus. Thus, the triangular hypoproct probably belongs to the ground-plan of the tribe, and its presence in the new species suggests that the lineage which it descends from dates back to the early stages of the genus' evolution. This makes sense in the light of the distribution area of $O$. mesorientalis sp.n., which lies far away from both the Caucasus, inhabited by the 
bulk of congeners, and the circum-Balkan region, where four (sub)species are known to occur: O. platyurus (Latzel, 1884) (southern Carpathians, Romania and Serbia), O. beroni (Strasser, 1973) (Rhodope Mts, Bulgaria), O. strasseri Vagalinski et Lazányi, 2018 (Andros Island, Greece), and O. brachyurus thassensis (Mauriès, 1985) (Thassos Island, Greece). Such a distribution pattern suggests that Omobrachyiulus could have once been even more speciose and widespread throughout the eastern Mediterranean realm in a broad sense. At some point in the geological past the genus must have reached the Caucasus, where it has since undergone active speciation in isolation. The Greater Caucasus is known to have been surrounded by the Eastern Paratethys through much of the Miocene and early Pliocene [Meulenkamp, Sissingh, 2003; Popov et al., 2006], Omobrachyiulus still thrives there today, while over the rest of its distribution area it must have faced a considerable decline, with only several relict species having survived until today. Map shows the distribution of $O$. mesorientalis sp.n.

Acknowledgements. The second author wishes to thank Eviatar Nevo and Tomáš Pavliček, both Haifa, Israel, who rendered him most of the Israeli samples for study, as well as Jolanta Wytwer, Warsaw, Poland, who helped him take pictures contained in Figs 1-4. Special thanks go to Petar Beron, the collector, and Pavel Stoev, the Keeper of Myriapoda at the National Museum of Natural History in Sofia, Bulgaria, whose sample from Lebanon is used in the present study.

\section{References}

Attems C. 1899. Neues über paläarktische Myriopoden // Zoologische Jahrbücher, Abtheilung für Systematik, Ökologie und Geographie der Thiere. Jg.12. S.286-336.

Golovatch S.I. 1981. Some new forms of millipedes (Diplopoda) from the Caucasus // Annales Zoologici. Vol.36. No.5. P.105116.

Lohmander H. 1928. Neue Diplopoden aus Ukraine und dem Kaukasus. (2. Aufsatz über Diplopoden aus dem Sovjet-Gebiet) // Académie des Sciences de 1'Ukraine, Mémoires de la Classe des Sciences Physiques et Mathématiques. Vol.6. No.3. P.529550 .

Lohmander H. 1936. Über die Diplopoden des Kaukasusgebietes // Göteborgs Kungliga Vetenskaps- och Vitterhets-Samhälles handlingar, 5 (Följden), Series B. Bd.5. No.1. S.1-196.

Meulenkamp J.E., Sissingh W. 2003. Tertiary palaeogeography and tectonostratigraphic evolution of the Northern and Southern Peri-Tethys platforms and the intermediate domains of the African-Eurasian convergent plate boundary zone // Palaeogeography, Palaeoclimatology, Palaeoecology. Vol.196. P.209228.

Popov S.V., Schherba I.G., Ilyina L.B., Nevesskaya L.A., Paramonova N.P., Khondkarian S.O., Magyar I. 2006. Late Miocene to Pliocene palaeogeography of the Paratethys and its relation to the Mediterranean // Palaeogeography, Palaeoclimatology, Palaeoecology. Vol.238. No.1. P.91-106.

Vagalinski B., Lazányi E. 2018. Revision of the millipede tribe Brachyiulini Verhoeff, 1909 (Diplopoda: Julida: Julidae) with descriptions of new taxa // Zootaxa. Vol.4421. No.1. P.001142.

Verhoeff K. 1921. Chilognathen-Studien (91. Diplopoden-Aufsatz) // Archiv für Naturgeschichte. Bd.86A. H.12. S.23-80.

Responsible editor K.G. Mikhailov 